\title{
Constructing Practical Teaching System of International Trade Major Based on CDIO Engineering Education Concept*
}

\author{
Zhenhua YANG \\ ,Jiangxi Science and Technology Normal University \\ Business School \\ Nanchang, Jiangxi, china \\ yzh340@126.com
}

\author{
Qiang SHEN \\ Nanchang University \\ Institute of Economic Management \\ Nanchang, Jiangxi, china \\ email:qiangsq@gmail.com
}

\begin{abstract}
The international trade major has relatively strong practical feature and shows high requirement on the practical teaching. Based on analyzing the increasing requirements specified by the enterprises towards the foreign trade personnel's practical skill and ability, this paper points out the reality problems of the universities in the international trade major, and puts forward building practical teaching system of international trade major based on CDIO (Conceive-Design-ImplementOperate) engineering education mode, as well as specific thought, steps and supporting construction.
\end{abstract}

Keywords-CDIO engineering education mode; Practical teaching system; International trade major.

\section{INTRODUCTION}

In 2014, the total trade volume of China reached USD4300 billion, ranking $1^{\text {st }}$ over the world, which presents that China was listed as a big trade country. Under such circumstance, the export-oriented enterprises have shown greatly increasing demands for the practical international trade personnel with high quality, which means that they put forward new requirements on cultivating such personnel in the universities. However, at present, the personnel training of our international trade major cannot adapt to the demands, as most universities put more emphasis on the theory but less on the practice, and there are also many problems in the practical teaching. It results in weak vocational skills and quality of the graduates. The students tend to adapt to the work only after long-term transition period.

\section{THE ENTERPRISES SHOW CONSTANTLY INCREASING REQUIREMENT ON THE PRACTICAL SKILLS OF THE FOREIGN TRADE PERSONNEL}

The export-oriented enterprises' requirements on the foreign personnel are not only reflected on the quantity, but also on the personnel quality and capability. They not only should master the latest professional knowledge, but also

* This research was supported by a grant from the Twelfth Five-year Plan Research Programs of Education Science Foundation of Jiangxi Province (No. JXJG-14-10-2). should improve their skills and practical operation experience. Especially, many enterprises require the graduates from the international trade major can hold some qualification certificates issued by the country, such as the merchandiser, export sales staff, customs declarer, etc. In the Fig. 1, the foreign trade enterprises' requirements on the practical improvement ability of the university students and practice experience account for $19 \%$ and $12 \%$ respectively. However, the requirement on mastering the professional knowledge only accounts for $17 \%$, which is far lower than the requirement on the practice. [1]

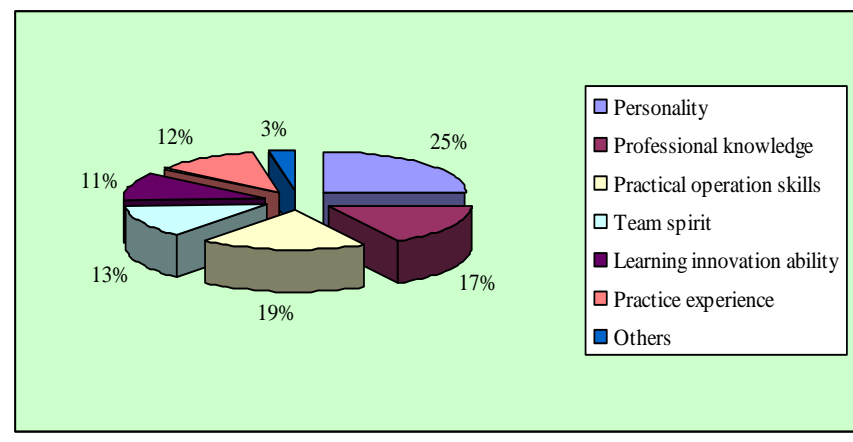

Fig. 1.The foreign trade enterprises' requirements on the university students' capability and quality in 2013

To possess practical operation ability is a kind of professional skill required for the international trade personnel. Most foreign enterprises in China are small and medium-size, and they are not willing to spend lots of time and money to cultivate personnel. Therefore, they hope to employ foreign trade salesmen who have certain practice experience and strong practical operation skills, and also are familiar with the foreign trade process. However, in China, the international trade major in most universities lays more emphasis on teaching theories, but less emphasis on the important practice courses, which gives rise to weak practice and operation ability of the students and influences their adaptability in actual work positions. From Fig. 2, it can be seen that the export-oriented enterprises hold that about $8 \%$ graduates have weak theoretical knowledge; 95\% graduates have weak practice ability; $72 \%$ graduates are not familiar with the foreign trade regulation and convention in 
the practice; $42 \%$ graduates are not familiar with the foreign trade business. However, they show quite low recognition degree towards the students' foreign language proficiency, and believe about $98 \%$ students should strengthen their foreign language proficiency. [2] Thus, it is clear that the practice ability of the graduates from the international trade major is really so weak.

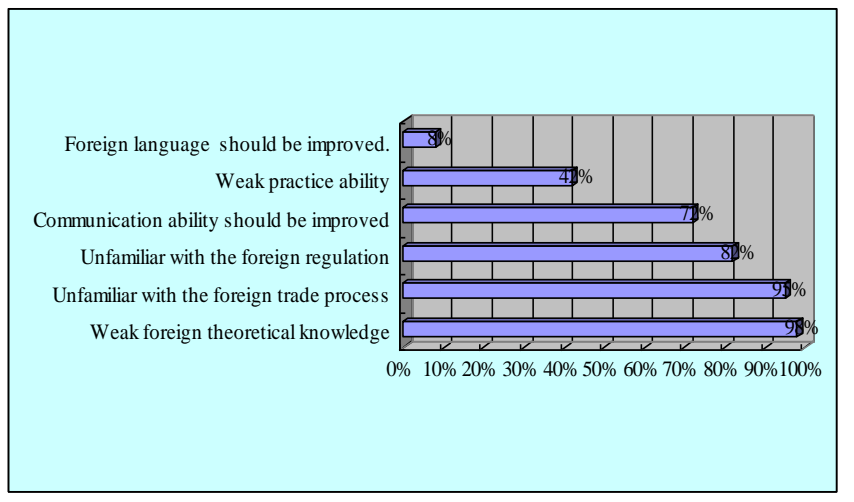

Fig. 2. Investigation results of the main problems of the graduates from the international trade major in the actual posts

\section{PROBLEMS IN THE PRACTICAL TEACHING SYSTEM OF THE TRADITIONAL INTERNATIONAL TRADE MAJOR}

The international trade is an application-oriented subject with strong technical skills. Therefore, the practical teaching is indispensable. However, in China, Most universities lay more emphasis on the theory for the international trade major but less emphasis on the practice. Besides, there are many problems in the practical teaching. Firstly, the international trade departments of most universities lack professional experimental facilities and laboratories. Students lack the opportunities of practicing import and export business, and cannot master the operation skills and methods of the foreign trade systematically. Secondly, although the universities arrange graduation internship, the internship seems to be quite formalistic due to the lack of the stable internship bases and strict standard examination methods. Thirdly, most teachers from the international trade major have heavy teaching and scientific research task, so that they do not have enough time to get involved in the enterprise practice. Thus, their practical operation ability is weak and they lack practical experience. They cannot well organize and guide the practical teaching. Fourthly, the practical teaching quality supervision mechanism of the international trade major lacks management and quality consciousness, quality evaluation system and examination mechanism that are in line with the practical teaching feature, as well as the process supervision of the practical teaching.

\section{BUILD PRACTICAL TEACHING SYSTEM OF THE INTERNATIONAL TRADE MAJOR BASED ON CDIO ENGINEERING EDUCATION CONCEPT}

CDIO engineering teaching mode is the latest achievement after the reform of the international engineering education in recent years. As the education concept for guiding the engineering education personnel cultivation mode, it meets the rule of the modern technical personnel cultivation, with good prospect and promotion value. Besides, it has great reference significance for other disciplines. CDIO takes the whole process from conception, design, and implementation to operation as the carrier to cultivate students' application ability. In CDIO concept, the students' application ability not only includes the personal academic knowledge, but also includes the students' lifelong learning ability, team communication ability and system mastering ability. [3]During the process of carrying out innovative construction on the practical teaching system of the international trade major, it is necessary to focus on the educating and teaching reform trend of the domestic and foreign application-oriented personnel cultivation. However, CDIO education concept is advanced foreign engineering education mode, which has great reference significance for building the practical education system of the international trade major.

Table1. Summary Sheet of Vocational Skill of International Trade Major

\begin{tabular}{|c|c|c|c|}
\hline \multicolumn{2}{|c|}{$\begin{array}{l}\text { Ability } \\
\text { Classification }\end{array}$} & Main Ability Elements & \multirow{2}{*}{$\begin{array}{l}\text { Main } \\
\text { Curriculum } \\
\text { Setting }\end{array}$} \\
\hline \multirow{3}{*}{$\begin{array}{l}\text { Basic } \\
\text { Practice } \\
\text { skill }\end{array}$} & $\begin{array}{l}\text { Marketing } \\
\text { investigation } \\
\text { ability }\end{array}$ & $\begin{array}{l}\text { International market investigation } \\
\text { and forecasting } \\
\text { ability; advertising propaganda, } \\
\text { marketing planning, } \\
\text { international market exploration } \\
\text { ability }\end{array}$ & \\
\hline & $\begin{array}{l}\text { Accounting } \\
\text { statistics }\end{array}$ & $\begin{array}{l}\text { Accounting book registration, } \\
\text { statement } \\
\text { preparation and expense accounting } \\
\text { ability; }\end{array}$ & $\begin{array}{l}\text { Financial } \\
\text { accounting } \\
\text { fundamental, } \\
\text { statistics } \\
\text { principle }\end{array}$ \\
\hline & $\begin{array}{l}\text { Publicr } \\
\text {-elations, } \\
\text { negotiation }\end{array}$ & $\begin{array}{l}\text { Communicate effectively; possess } \\
\text { negotiation skills, } \\
\text { and control the negotiation } \\
\text { orientation; public } \\
\text { relation planning ability; ability of } \\
\text { resolving the crisis }\end{array}$ & $\begin{array}{l}\text { Commercial } \\
\text { negotiation, } \\
\text { public } \\
\text { relationship }\end{array}$ \\
\hline \multirow{4}{*}{$\begin{array}{l}\text { Compre } \\
\text { - } \\
\text { hensive } \\
\text { practice } \\
\text { ability }\end{array}$} & $\begin{array}{l}\text { International } \\
\text { business }\end{array}$ & $\begin{array}{l}\text { Ability of organizing the import } \\
\text { and export business; } \\
\text { deal with the foreign trade } \\
\text { contracts, and get proficient } \\
\text { in formulating sheets; ability of e- } \\
\text { commerce management }\end{array}$ & $\begin{array}{l}\text { Foreign } \\
\text { trade practice, } \\
\text { customs } \\
\text { clearance } \\
\text { training, } \\
\text { e-commerce } \\
\text { training }\end{array}$ \\
\hline & $\begin{array}{l}\text { International } \\
\text { settlement }\end{array}$ & $\begin{array}{l}\text { Ability of applying the foreign } \\
\text { trade settlement tools, } \\
\text { reviewing the letter of credit and } \\
\text { preventing } \\
\text { foreign exchange risk }\end{array}$ & $\begin{array}{l}\text { International } \\
\text { finance, } \\
\text { international } \\
\text { settlement }\end{array}$ \\
\hline & $\begin{array}{l}\text { International } \\
\text { cargo } \\
\text { transportation }\end{array}$ & $\begin{array}{l}\text { Ability of selecting transportation } \\
\text { way for } \\
\text { the import and export goods, } \\
\text { signing the transportation } \\
\text { contracts, serving as an agent for } \\
\text { the cargo transportation }\end{array}$ & $\begin{array}{l}\text { International } \\
\text { cargo } \\
\text { Transportation } \\
\text { and } \\
\text { insurance, } \\
\text { graduation } \\
\text { design }\end{array}$ \\
\hline & $\begin{array}{l}\text { Deal with the } \\
\text { Letters } \\
\text { and } \\
\text { telegrams }\end{array}$ & $\begin{array}{l}\text { Ability of discussing about the } \\
\text { foreign trade } \\
\text { and dealing with the daily business } \\
\text { and correspondence }\end{array}$ & $\begin{array}{l}\text { Foreign } \\
\text { business } \\
\text { correspondence }\end{array}$ \\
\hline
\end{tabular}

A. Construction idea about the practical teaching system of the international trade major

To build the practical teaching system of the international trade major should take the following three aspects into 
consideration. Firstly, it is necessary to reasonably formulate personnel cultivation targets; secondly, carry out deep research on the practical teaching content, and formulate scientific teaching process and method according to the feature of the practical teaching links; thirdly, increase the fiscal input on the practical teaching, and improve the practical teaching condition from the hardware and software aspects, expand the practical teaching base construction, build real practical scenes, accelerate the improvement of the faculty application ability, and build a good practical teaching team; finally, standardize the teaching management, explore new practical teaching examination and evaluation system, build evaluation standards of each teaching link, monitor the teaching quality, and understand the teaching feedback.

\section{B. Construction steps about the practical teaching system of the international trade major}

\section{1) Reasonably formulate personnel cultivation targets.}

CDIO education concept advocates applied education has four important stakeholder groups: student, industry, teacher and society. The industry is the major stakeholder of the international trade major. The confirmation of the professional personnel cultivation target and cultivation proposal comes from the comprehensive analysis and investigation on the foreign trade industry. It is necessary to apply the deep analysis and long-term tracing method, carry out investigation on the enterprises involved in foreign trade industry, comprehend the comprehensive evaluation form the enterprises towards the graduates' employability, quality and evaluation on the professional teaching effect of the school; comprehend the influence of the distribution status of the post demands, regional economy and industry structure adjustment on the demands for the graduates; comprehensively analyze all investigation information, regard it as the reference for determining the talent cultivation target and curriculum planning; improve the scientificalness and rationality of the personnel cultivation target and curriculum planning formulation. For author/s of only one affiliation

2) Analyze and determine the professional ability and quality requirements

Take the personnel cultivation target and education concept as the guidance, integrate with the development demands of the local foreign trade industry, regard the practice and innovation ability cultivation as the fundamental and the cultivation of the students' foreign trade service capability as the principal line, analyze and determine the quality and professional requirements composed of the professional elementary practice ability, professional comprehensive practice ability, innovation ability and social adaptability, and take the international trade major as an example. [4]The professional ability cultivation is shown in table 1. CDIO holds that the applied education has four important

3) Comprehensively build practical teaching system of the international trade major

To ensure the fulfillment of the personnel cultivation target, the practical teaching system of the international trade major should be built based on four modules, i.e. practical training, vocational certificate acquiring, internship, and dissertation writing. As shown in Fig.3, the first one is the practical training. It is feasible to take the basic skills, professional skills and integrated skills as the basis to carry out the practical training arrangement, and cultivate students' cognition ability and adaptability. The second one is acquiring the professional vocational certificates. The students can take part in holding various vocational qualification certificate examination held by the country through the curriculum study and practical skill training, and obtain the corresponding vocational certificate and the practitioner skill certificate of the international trade. The next one is internship, it refers that the students apply the knowledge they have learned, and solve the problems and proceed with the knowledge innovation. It is feasible to transform the applied subjects the teachers are working or have finished to the practice projects, or let the students get involved in the enterprises, carry out the practical teaching aiming at the actual projects, and then cultivate students' practical operation ability and communication ability, and then enable them to blend into the vocational roles rapidly after graduation. The last one is the dissertation. [5] It is the last step of the practical teaching. In this step, the students apply the basic knowledge and theory, and study the practical feature of the actual problems. It has the creative and practical characteristics. Besides, it is regarded as an important practical teaching link for the universities to cultivate students' innovation ability, practice ability, and entrepreneurship spirit.

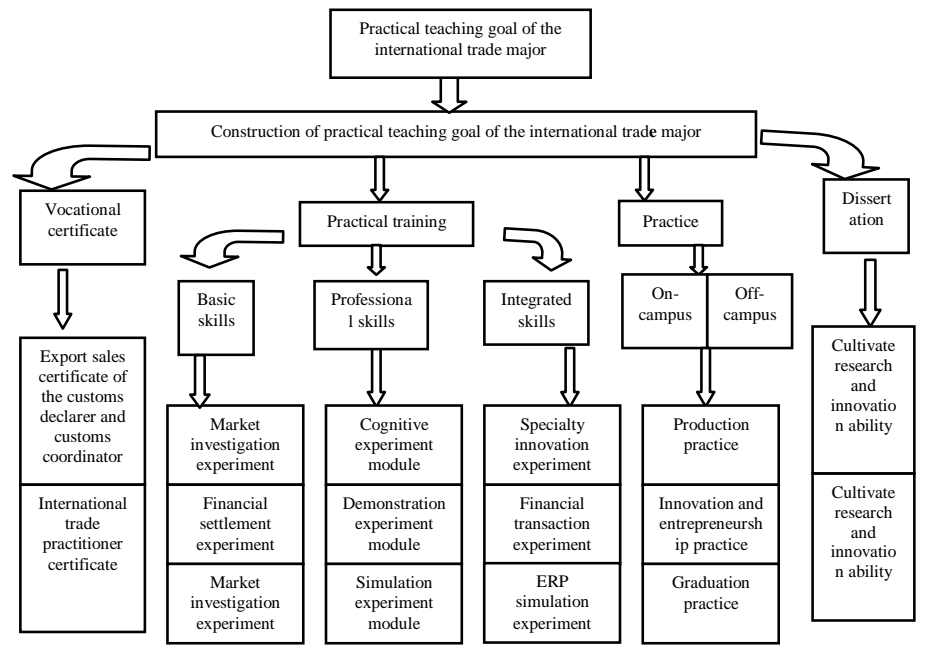

Fig.3. Content system of practical teaching system of international trade major

\section{Supporting construction of the practical teaching system of international trade major}

\section{1) Faculty construction}

CDIO puts forward that, if the teachers are expected to teach the course integrated with the disciplinary knowledge product, process and system construction ability, they must master these abilities. Therefore, it is feasible to start it from the faculty construction as follows. Firstly, it is necessary to speed up the teachers' education concept transformation and knowledge updating, let the young teachers take temporary posts in the enterprises for practice, and accelerate the improvement of the knowledge update and professional 
proficiency. Secondly, transform the teachers' scientific research achievements into the teaching content, and transform the applied subjects that the teachers are working on or have already completed to the practice subjects, and carry out the practical teaching. [6] Thirdly, cultivate "double-qualified" teachers. Employ the professional technicians who can master the core ability of the corresponding industry to serve as the part-time teacher to participate in the teaching and become "double-qualified" teachers.

2) Practical teaching condition construction and practical teaching management

With respect to the specialized laboratory construction, constantly build and transform the current laboratories, and build the system that provides professional practical teaching service to the students. Inside and outside the school, build a teaching practice base with the innovation ability and entrepreneurship ability training, integrated with the laboratory, internship, simulation training and post practice, and meet the demands for the students' practice and dissertation. With regard to the practical teaching management, it is necessary to develop networked information system platform of the international trade, and provide laboratory reservation service, information consulting, on-line answer, and course arrangement to the students; provide on-line guidance, various sheet formulation and experiment assessment process to the teachers, etc. Provide curriculum design and comprehensive practice project management platform; adopt the engineering project quality process control and quality management method to strengthen the quality control on the comprehensive, designing and innovative practice project.

\section{REFERENCES}

[1] Information on http://www.jobui.com/ and http://www.mycos.com.cn

[2] Liu Wei. Research on Application-oriented Personnel Cultivation Mode in Practical Teaching [J]. Experimental Technique and Management, vol 9.2009, pp.123-127.

[3] Claure. Recognition on Engineering Education: International CDIO Cultivation Mode and Method. Gu Peihua, Shen Minfen, Lu Xiaohua. Beijing: Higher Education Press, 2005.

[4] Li Ming, Dan Wu. The recearch on International Trade professional Practice Teaching.Journal of Henan Institute of Science and Technology vol.10.2011.pp:112-115.

[5] Zhijun Sheng, Ming Zhao, Xiao Zhang, The Practice of International trade Professional 's Applied Talents Training in Common Colleges and Universities Journal of Changchun University of Science and Technology (Social Science Edition) 2011, vol. 8. pp:126 - 128.

[6] Ding Jie. Current Situation Analysis and Strategy of Young Teachers in Newly-promoted Local Universities and Colleagues. Helonjiang Higher Education Research, vol. 2. 2006 , pp.: 95-97. 